\title{
Celina Frade*
}

\section{Generic variation across legislative writing: A contrastive analysis of the UNCITRAL Model Law and Brazil's Arbitration Law}

\begin{abstract}
The nature of legislation is to control human relations and actions by words. Legislative writing displays relative uniformity though, as a genre, some variations are allowed across legal systems, as in the case of arbitration laws. This article focuses on the generic variation of two arbitration laws: the UNCITRAL Model Law on the International Commercial Arbitration (hereafter UNCITRAL) and the Brazilian Arbitration Law 9.307/1996 (hereafter BAL). Arbitration is an alternative form of conflict resolution based upon the free will of the parties to invest arbitrators, (not the judiciary) with the jurisdiction to settle disputes in a contract of commercial nature. The claim is that the analysis (at surface level) of textual organization and legislative style in the data cannot account alone for an explanation of how legislative information is functionally realized in order to achieve its communicative intent. To explain this we, therefore, also consider how legislative information is packaged by means of some textualization devices (qualificational insertions, binomial and multinomial structures and textual-mapping) and conclude by showing how recontextualization is realized in the data by means of generality, fuzziness and vagueness of terms and expressions.
\end{abstract}

\section{Introduction}

Law is a social institution which comprises both a set of (predominantly written) codes of laws to regulate human relations and processes for applying them and disputing their application (Gibbons 1999). In the two main contemporary legal systems - the common law and the civil law - legislation is the largest and the most powerful source of law and appears in several forms of genres, such as enacted laws

\footnotetext{
Celina Frade

celinafrade@uol.com.br
} 
(acts of parliament, statutes or normative acts), and judicial decisions, formulated in a highly specialized and contextually dependent language.

As a genre, legislative writing displays relatively uniform features across legal systems while variations are also allowed due to historical developments and the imposition of societal norms wherein they apply. Nowadays, with the (pre)dominance of English as the language of international trade and business, there has been a tendency for uniformity and standardization in transnational legislation to optimize global communication, as in the case of arbitration. Also, legislation across legal system can display variations in their textual organization and in the strategic use of textualization devices.

This article focuses on the generic variation of two arbitration laws: the UNCITRAL Model Law on the International Commercial Arbitration (hereafter UNCITRAL) and the Brazilian Arbitration Law 9.307/1996 (hereafter BAL) ${ }^{1}$. It starts with a brief account of the common law and the civil law legal traditions and their law languages. Next, we approach legislative writing as a genre and its variations according to legal system's usage. Then, we provide a detailed description of the data and a contrastive analysis of their textual organization and legislative style. We move on to show how legislative information is packaged in the laws in relation to the following textualization devices: qualificational insertions, binomial and multinomial structures and textual-mapping. To conclude, we approach legislative recontextualization and its relevance to law interpretation in terms of generality, fuzziness and vagueness of terms and expressions. We round off the article by suggesting further research.

1 The original text of the UNCITRAL is available at: www.uncitral.org. The original text of the BAL is available only in Portuguese in the issue of the Official Gazette [Diário Oficial] dated Tuesday, September, 24, 1996. Due to its length, it has not been attached to this article. A free translation of some of its clauses in English is provided in the examples and the original version in Portuguese is provided in footnotes. 


\section{Legal systems and their languages}

Legal systems vary according to the origins and historical developments they encode. Likewise, law-making processes and "rhetorical thought patterns" (Widdowson 1979:155) display variations as expressed in particular conventions of description and argument in the use of law languages, including legislative writing, across (and within) legal systems.

The common law and the civil law are the two main contemporary legal systems. The common law, developed in England from the time of the Norman Conquest (A.D. 1066), was spread throughout the world by the British Empire. Its fundamental principles are based on court decisions together with individual cases, on the doctrines implicit in those judicial decisions and on customs and usages rather than on codified written laws. However, in the contemporary common law countries, there is also an increasing bulk of enacted law, "due to the interventionist policies of the state" (Dascal and Wróblewski 1991: 428).

In contrast, the civil law, based on Roman law and the canonic law as codified in the French or Napoleonic Code (894), established a systemic and principled legal method. It is framed by political histories which led to codifications of law and a "bureaucratic view of the courts as instruments of democratic state power" (Campbell 1996). The main source of law is the enactment of normative acts which are regarded as "unilateral decisions of the competent state organ" (Dascal and Wróblewski 1991:428).

The common law has produced a legal language which is detailed, technical and generally conservative, revealing the great antiquity of the system. The text, and not its intent, is the most important source of interpretation; it restricts the judges' interpretations. Much of the terminology used in the common law legislation today can only be explained by going back to medieval times in England and it still displays orality residues of oral arguments used in court in its early history (Hogue 1986 and Danet and Bogoch 1994).

The language of civil law favors a rather intelligible and simple style since it is supposed to be understood by the ordinary citizen who, on the other hand, has to rely on legal advice to have their rights assured. The fundamental assumption is that no interpretation can be dissociated 
from a "general legislative intent covering all legal relations within the national society" (Campbell 1996) and the role of the court is to treat the text as a guide only and to establish the details of its application in specific cases.

In both legal systems, legislative writing can be regarded as a relatively uniform genre with permissible variations according to its usage.

\section{Legislative writing: variations of the same genre}

In order to achieve its goal to control actions and activity types by words, legislation has developed "norms, routines and interactional patterns, so that we could talk about 'genre' being associated with [it]" (Linell 1998a:239). Thus as a genre, legislative writing is based on relatively similar rhetorical practice organized around recurrent actions or situations whereby we understand situations that are comparable, similar or analogous to other legislative situations (Miller 1984). More strictly, legislative writing refers to "obligatory solutions to [the] specifically communicative problems' [the author's emphasis] (Luckmann 1989:160) of regulating human relations and restoring social order in case it breaks down ${ }^{2}$. However, in spite of generic similarity, we do find permissible generic variations in legislative writing across legal systems which cannot be "adequately appreciated unless the context in which they operate is taken into account" (Akman 2000: 753).

2 See Danet 1980 and 1984 for a comprehensive account of this issue. 


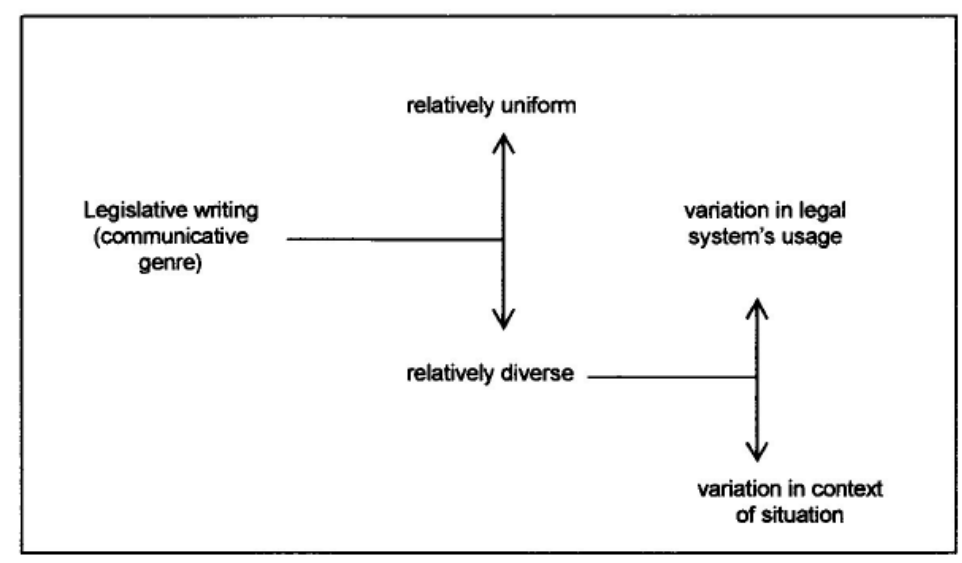

Figure 1: Variation in legislative writing

Figure 1 depicts the possible variations within the genre in question, following Quirk et al. (1985:31). The vertical poles represent a 'moreor-less' opposition: the upper pole of the first vertical corresponds to the features of greatest uniformity which comprise "the main stable, common core" or the prototypical features of the genre and the lower pole of the first vertical corresponds to the "area of fluctuation" (p.31). The second vertical represents the situations in which there may be permissible fluctuations either in legal system's usage (the higher pole) or in the context of situation (the lower pole). In this case, "deviations from the prototypical central core" allow a much more flexible approach in determining the genre than its classification into clear-cut categories (Paltridge 1995:395).

Legislative genre, like any discourse, genre or text, is also embedded in a "matrix of contexts made up from an array of different contextual resources" (Linell 1998b:144). The contexts of legislative interpretation are construed as satisfying some presuppositions of what is shareable and shared by the law-maker and the law-interpreter/ applier. On the production side, the law-maker has the authority of the legislature (standing for the sovereign power or the government) and is assumed to be a competent user of legal language and of relevant rules of legal reasoning; on the reception side, there are those subject to the legislation (the audience) and the law-interpreter/applier, who is 
assumed to have access to the following contextual resources: a legal language, the situational context of legislation, the relevant rules of legal language, a legal system and directives of legal interpretation (Dascal and Wróblewski 1991).

The UNCITRAL and the BAL are instances of generic variations of legislative writing. Both regulate the same activity type - the constitution of arbitration - providing for the definition of the situation for the parties, the description of their joint activities bounded by a set of routinized phases or moves and the guidance for proper interpretation/application of actions and events lodged within them. The description of the data and a detailed surface level analysis of their textual organization and legislative style are the topics of the next section.

\section{The data}

The UNCITRAL and the BAL provide for the rules and process of constitution of arbitration at both national and international levels. Arbitration is a means of settling controversies arisen out of contractual transactions which has become increasingly popular worldwide. It consists of an alternative dispute-resolving process - different from the classical lawsuit - based upon the free will of the parties who invest arbitrators with the power to decide upon the dispute and whose decision has the same effect as a judicial sentence. Among its main advantages are secrecy, speed, low costs and, according to De Orleans e Bragança (1999:20):

$/ . . /$ the absence of solemn forms, the possibility of judgment by equity and/or free choice of law to be applied. Furthermore, the arbitrators offer neutrality in the settlement of the issue involving parties of different nationalities, and judge with technical specialization.

Arbitration is very often referred to as a supranational lex mercatoria due to the multiplicity and variety of arbitral solutions based upon equity, general rules of law and common practice of international trade. Moreover, the spread of international arbitral treaties, conventions and associations and the "identification, mobility and transnationality in the application of arbitral rules" [the author's emphasis] in case of ad hoc, national or international arbitrations have contributed to its increasing popularity (Garcez 1999:179). 
The UNCITRAL was adopted by the UN Commission on International Trade Law (UNCITRAL) in June 1985. It was designed in view of "the desirability of uniformity of the law of arbitral procedures and the specific needs of international commercial arbitration practice" since, according to a global survey, national laws on arbitration revealed "considerable disparities" as to individual provisions and solutions and also in terms of development and refinement. The UNCITRAL aims at constituting a "sound and promising basis for the desired harmonization and improvement of national laws", covering all stages of the arbitral process: from the arbitration agreement to the recognition and enforcement of the arbitral award. It reflects the worldwide consensus on the principles of international arbitration practice and gives flexibility to the states to prepare new arbitration laws. And it also claims to be acceptable to all states and the different legal or economic systems of the world and hence it can be followed "as closely as possible".

In Brazil arbitration has only attained global status with the enactment of the BAL by former President Fernando Henrique Cardoso on 23rd September 1996, which was partly inspired by the UNCITRAL (more details in Frade, 2003). On the socio-legal level, the BAL forms part of the democratization process which the country has gone through in the last decades, providing Brazilian citizens with a free, modern, quick and more cost-effective access to justice. On the cultural level, not only does the BAL represent the birth of "a new disputing culture" within national legal practice and institutions towards mediation and arbitration but also within the "subjective perspective" (Zariski 2000) of Brazilian legal practitioners as far as their new roles in legal globalization are concerned.

Next we will examine the "outward appearance" (Widdowson 1979: 61) of the data with regard to textual organization and legislative style.

\subsection{Textual organization}

The UNCITRAL and the BAL display relatively uniform textual organization (see Table 1) and a rhetorical 4-move 'arbitration' interchange pattern (Frade 2002a). The layout is meant to serve as a visual device to identify and separate the component parts of the rule, numbered or lettered headings and subheadings, presented in a rather arbitrary 
order. Provisions are loosely organized as a "colony discourse" type, according to Hoey's metaphor (1986:4): they are similar to 'beehives' or 'ant-hills' insofar as each section is a self contained organism (like bees and ants) as part if its colony (the law itself) and has no utility separated from it.

The UNCITRAL follows the rules of contract drafting more closely than of statutes or legislation (see Child 1992 and Trosborg 1997). It has a long capitalized title - 'UNCITRAL MODEL LAW ON INTERNATIONAL COMMERCIAL ARBITRATION'-, the number of the document - 'United Nations document A/40/17, Annex I' - and a short explanation as to the subject-matter and the day of the enactment in brackets - (As adopted by the United Nations Commission on International Trade Law on 21 June 1985.).

The UNCITRAL has 5.263 words and 173 paragraphs. It is divided into eight chapters and thirty-six articles. Headings are used for the chapters and subheadings for articles, whereas the numbering of items follows an interrupted numerical sequence from the first article until the last one and employs cardinal numbers between brackets. It also includes a definition section (Article 2) for the wanted meaning of the terms 'arbitration, 'arbitral tribunal' and 'court'. A footnote in Article 1 (1), provides that the term 'commercial' should be given a "wide interpretation so as to cover matters arising from all relationships of a commercial nature, contractual or not". The terms defined in Article 2 do not take usual initial capitals, which can be explained by the fact that as a model law, it leaves to the parties discretion to provide for a more detailed definition of these terms in other contexts of application.

The BAL is shorter than the UNCITRAL and has 4.003 words and 161 paragraphs. It follows strictly the Decree 4.176/2002 that provides for Brazilian legislative drafting style (see Frade 2003). The title contains the number and the date of the enactment, 'Law no 9.307, of September 23, 1996', followed by the short title 'Provides for arbitral proceedings'.

The BAL is organized into seven chapters, forty-one articles and forty-nine paragraphs. The articles are numbered in ordinal numbers and its symbol ' $\mathrm{o}$ ' and the paragraphs are marked with the symbol ' $\S$ ' preceding an ordinal number. Capitalized headings are given only to the chapters and there are no subheadings for the articles, which 
makes it more difficult to deduce the details of the subject-matter. The preference is to provide more general headings for the chapters which results in "information-overlap" and a lack of logical sequence. The BAL does not display a definition section and adheres to the civil law drafting tradition of defining terms, when necessary, within the body of the document and without using initial capitalization.

\begin{tabular}{|c|c|}
\hline UNCITRAL & BAL \\
\hline $\begin{array}{l}\text { Chapter I. General Provisions } \\
\text { Article 1. Scope of application } \\
\text { Article 2. Definitions and rules of interpretation } \\
\text { Article 3. Receipt of written communication } \\
\text { Article } 4 \text {. Waiver of right to object } \\
\text { Article 5. Extent of court intervention } \\
\text { Article 6.Court or other authority for certain } \\
\text { functions of arbitration assistance and } \\
\text { supervision }\end{array}$ & $\begin{array}{r}\text { Chapter I. GENERAL PROVISIONS } \\
2 \text { Articles } \\
2 \text { Sections }\end{array}$ \\
\hline $\begin{array}{l}\text { Chapter II. Arbitration agreement } \\
\text { Article } 7 \text {. Definition and form of arbitration } \\
\text { agreement } \\
\text { Article } 8 \text {. Arbitration and substantive claim } \\
\text { before court } \\
\text { Article } 9 \text {. Arbitration agreement and interim } \\
\text { measures by court }\end{array}$ & $\begin{array}{r}\text { Chapter II. ARBITRATION AGREEMENT AND ITS EFFECTS } \\
10 \text { Articles } \\
11 \text { Sections } \\
1 \text { Paragraph }\end{array}$ \\
\hline $\begin{array}{l}\text { Chapter III. Composition of arbitral tribunal } \\
\text { Article 10. Number of arbitrators } \\
\text { Article 11. Appointment of arbitrators } \\
\text { Article 12. Grounds for challenge } \\
\text { Article 13. Challenge procedure } \\
\text { Article 14. Failure or impossibility to act } \\
\text { Article 15. Appointment of substitute arbitrator }\end{array}$ & $\begin{array}{r}\text { Chapter III. THE ARBITRATORS } \\
6 \text { Articles } \\
11 \text { Sections } \\
1 \text { Paragraph }\end{array}$ \\
\hline $\begin{array}{l}\text { Chapter IV. Jurisdiction of arbitral tribunal } \\
\text { Article } 16 \text {. Competence of arbitral tribunal to } \\
\text { rule on its jurisdiction } \\
\text { Article } 17 \text {. Power of arbitral tribunal to order } \\
\text { interim measures }\end{array}$ & $\begin{array}{r}\text { Chapter IV. ARBITRAL PROCEEDINGS } \\
4 \text { Articles } \\
11 \text { Sections } \\
1 \text { Paragraph }\end{array}$ \\
\hline $\begin{array}{l}\text { Chapter V. Conduct of arbitral proceedings } \\
\text { Article 18. Equal treatment of parties } \\
\text { Article 19. Determination of rules of procedure } \\
\text { Article 20. Place of arbitration } \\
\text { Article 21. Commencement of arbitral } \\
\text { proceedings } \\
\text { Article 22. Language } \\
\text { Article 23. Statements of claim and defence } \\
\text { Article 24. Hearings and written proceedings } \\
\text { Article 25. Default of a party } \\
\text { Article 26. Expert appointed by arbitral tribunal } \\
\text { Article 27. Court assistance in taking evidence }\end{array}$ & $\begin{array}{r}\text { Chapter V. THE ARBITRAL AWARD } \\
11 \text { Articles } \\
5 \text { Sections } \\
4 \text { Paragraphs }\end{array}$ \\
\hline
\end{tabular}




\begin{tabular}{|c|c|}
\hline $\begin{array}{l}\text { Chapter VI. Making of award and termination } \\
\text { of proceedings } \\
\text { Article 28. Rules applicable to substance of } \\
\text { dispute } \\
\text { Article 29. Decision making by panel of } \\
\text { arbitrators } \\
\text { Article } 30 \text {. Settlement } \\
\text { Article 31. Form and contents of award } \\
\text { Article 32. Termination of proceedings } \\
\text { Article 33. Correction and interpretation of } \\
\text { award: additional award }\end{array}$ & $\begin{array}{r}\text { Chapter VI. RECOGNITION AND ENFORCEMENT OF } \\
\text { FOREIGN ARBITRATION AWARDS } \\
7 \text { Articles } \\
2 \text { Paragraphs }\end{array}$ \\
\hline $\begin{array}{l}\text { Chapter VII. Recourse against award } \\
\text { Article } 34 \text {. Application for setting aside as } \\
\text { exclusive recourse against arbitral award }\end{array}$ & $\begin{array}{r}\text { Chapter VII. FINAL PROVISIONS } \\
3 \text { Articles }\end{array}$ \\
\hline $\begin{array}{l}\text { Chapter VIII. Recognition and enforcement of } \\
\text { awards } \\
\text { Article 35. Recognition and enforcement } \\
\text { Article 36. Grounds for refusing recognition or } \\
\text { enforcement }\end{array}$ & \\
\hline
\end{tabular}

Table 1: the textual organization of the UNCITRAL and the BAL

Unlike the UNCITRAL, the BAL may be regarded as a 'macro hybrid speech act' ${ }^{3}$ which combines three types of speech acts and the two performers of the act contained in this formula. Its 'declarative' formula - 'I make known' - is presented in the beginning of the document in which the grammatical and real subject of the sentence is the President who 'declares' something. The National Congress performs one of its attributions to 'decree' the law and then the President also performs his/ her other attribution to 'sanction' the law. The predicate 'the following Law' is a place holder since "the real subject, extra-posed to the end of the sentence is the entire text of the law" (Kurzon 1986:11):

I make known that the National Congress decrees and I sanction (the entire text of the law that follows).

It is also worth pointing out that, in both laws, most of the individual articles, sections and paragraphs are performative each with their own explicit performative verbs such as 'agree', 'decide', 'challenge', 'request', and so on.

3 See van Dijk 1977 for a detailed account of 'macro speech act' and Hancher (1979) for 'hybrid speech act'. 


\subsection{Legislative style}

The UNCITRAL displays some traditional features of common law legislative style albeit being rather easified in its attempt to serve as a model law for other states. The typical sentence is rather long, complex and consists of two or more coordinated main clauses and/or have one or more subordinate clauses that function as an element of the sentence, respectively (Quirk et al 1985). Sentence length and complexity are also explained by the strategic use of self-contained and all-inclusive sentences, the way information is packaged (see section 5), and recontextualization (see section 6).

However, most of the characteristics which account for complexity in common law legislative style have been traditionally associated with legal English in general and do not have any legal significance. Rather, they are regarded as clichés or mannerisms, "to which lawyers can claim neither priority or monopoly" (Mellinkoff 1963:24).

Self-contained sentences condense all the necessary information within their syntactic boundaries so that their interpretation does not depend necessarily on what is written previously or subsequently. On the other hand, all-inclusive sentences show the typical legal concern with explicitness and precision in an attempt to cover all future contingencies and to avoid ambiguities at all costs (Mellinkoff 1963 and Bhatia 1993).

Here is an example of a 87-word-long sentence in the UNCITRAL.

[1] Article 13. Challenge procedures

(3) If a challenge under any procedure agreed upon by the parties or under the procedure of paragraph (2) of this article is not successful, the challenging party may request, within thirty days after having received notice of the decision rejecting the challenge, the court or other authority specified in article 6 do decide on the challenge, which decision shall be subject to no appeal While such a request is pending, the arbitral tribunal, including the challenged arbitrator, may continue the arbitral proceedings and make an award.

The BAL follows closely the Brazilian legislative style and its plain and reader-friendly (though formal) style seems to rely heavily on the tacit shared knowledge of Brazilian legal professions who use the text as a guide only (Maley 1987 and Bhatia 1993). In contrast to the UNCITRAL, the BAL displays short and simple sentences with little 
explicitness and not totally self-contained in that their interpretation is subordinated to a set of more general provisions from which it cannot and should not be dissociated (see section 6).

Example [2] below is the corresponding 38 word long sentence of [1] in the BAL

[2] $15^{\text {th }}$ Art. The party interested in challenging the refusal of the arbitrator shall present, in accordance with art. 20, the respective request directly to the arbitrator or the chairman of the arbitral tribunal, explaining his reasons and presenting due evidence ${ }^{4}$.

Textual organization and legislative style are easily recognizable when analyzing the texts per se. This textual approach is concerned with how the language system is formally manifested and with the quantitative analysis of "what linguistic forms occur and how frequently" (Widdowson 1979:57). However, these surface features alone cannot explain how legislative information is functionally realized in order to achieve its communicative intent. Our next discussion then will focus on how legislative information is packaged in the laws by analyzing the following textualization devices: qualificational insertions, binomial and multinomial structures and textual-mapping.

\section{The packaging of legislative information}

The term 'information (or linguistic) packaging' has been used to refer to phenomena "having less to do with the content of an utterance than with the way that content is wrapped up and presented to the [reader]"(Chafe 1984:21). Although the author is concerned with information status in spoken discourses (Chafe 1976 and 1984), our concern here is with the restricted values which certain linguistic elements take on, or are textualized, in the packaging of information in the data.

In legislative genre, textualization devices include qualificational insertions, binomial and multinomial structures, textual-mapping and recontextualization. Although these devices are not necessarily

4 Art. 15. A parte interessada em argüir a recusa do árbitro apresentará, nos termos do art. 20, a respectiva exceção, diretamente ao árbitro ou ao presidente do tribunal arbitral, deduzindo suas razões e apresentando as provas pertinentes. 
displayed in the same way across law languages and their occurrence are not frequent and systematic enough to be associated with the genre, they tell us "what the forms count as communication, how they express elements of discourse"(Widdowson 1979:57).

\subsection{Qualificational insertions}

Qualificational insertions, or qualifications, can be defined as explanatory or restrictive pieces of information inserted immediately next to the item it is supposed to specify in the provision. As Bhatia (1993) points out, without qualifications, the provision would be too general and of universal application. The inserting of various qualifications within the boundaries of legislative sentences increases the degree of the syntactic discontinuity and information load in the provisions causing serious reading problems (Bhatia 1984, Kurzon 1985 and Berman 1989).

There are three types of qualifications in legislative sentences which provide three different types of information about the provision. The preparatory qualification outlines the description of the provision to which the rule of law applies; the operational qualification adds information to the operation of the provision and the referential qualification specifies the "inter-textual nature of the legislative provision"(Bhatia 1993:114-115). Here is a typical instance of a legislative sentence with qualificational insertions in the UNCITRAL:

[3] Article 12. Grounds for challenge

(1) When a person is approached in connection with his possible appointment as an arbitrator, he shall disclose any circumstances likely to give rise to justifiable doubts as to his impartiality or independence.

An arbitrator, from the time of his appointment and throughout the arbitral proceedings, shall without delay disclose any such circumstances to the parties unless they have already been informed of them by him.

By verticalizing the provision above, the syntactic discontinuities become more clear.

[4] Article 12. Grounds for challenge (a) When a person is approached in connection with his possible appointment as an arbitrator, he shall disclose any circumstances likely to give rise to justifiable doubts as to his impartiality or independence. 
(b) An arbitrator, from the time of his appointment and throughout the arbitral proceedings,

shall

without delay

disclose any such circumstances to the parties

unless they have already been informed of them by him.

In sentence (a), the underlined and italicized provisionary clause is a preparatory qualification and the subsequent underlined clause applies to the description prefaced in it. In sentence (b), there are two italicized operational qualifications which interrupt the normal sequence of the sentence: the first one, after the subject 'an arbitrator', specifies when and how long the arbitrator shall disclose the circumstances mentioned and the second one discontinues the sentence after 'shall' to provide for a specification. In the same sentence, the operational qualification in bold is restrictive to everything that precedes it.

In the BAL, sentences are shorter and there are fewer explicit qualificational insertions, which contribute to a lighter level of information load. However, there are some 'invisible' or implicit qualifications recontextualized in the provisions and their specifications are to be found in the more general codified laws as the codes and the constitution (see section 6). Let us analyze an example of qualificational insertions in the BAL:

[5] Chapter IV. Arbitral Proceedings

$20^{\text {th }}$ Art. The party which intends to challenge matters related to the competence, suspicion or impediment of the arbitrator or arbitrators, as well as the nullity invalidity or inefficacy of the arbitration agreement, shall make it in the first opportunity it has to manifest itself, after the commencement of arbitration ${ }^{5}$.

By verticalizing [5], we can visualize one long underlined operational qualification after the subject 'the party' and another one in the end of the sentence.

5 Art. 20. A parte que pretender argüir questões relativas à competência, suspeição ou impedimento do árbitro ou dos árbitros, bem como nulidade, invalidade ou ineficácia da convenção de arbitragem, deverá faze-lo na primeira oportunidade que tiver de se manifestar, após a instituição da arbitragem. 
[6] $20^{\text {th }}$ Art. The party which intends to challenge matters

related to the competence, suspicion or impediment of the arbitrator or arbitrators,

as well as the nullity invalidity or inefficacy of the arbitration agreement,

shall make it in the first opportunity it has to manifest itself,

afte the commencement of arbitration.

Here is a more typical instance of the simplicity of qualification insertions in the BAL:

[7] Chapter III. The arbitrators

$\S 5^{\text {th }}$. The arbitrator or the chairman of the tribunal shall appoint, if they

deem convenient, a secretary, who may be one of the arbitrators ${ }^{6}$.

Syntactic discontinuity and complexity caused by qualificational insertions are quite typical in the UNCITRAL provisions for the sake of explicitness and precision. The same does not hold for the BAL as sentences are shorter and implicit qualifications prevail.

\subsection{Binomial and multinomial structures}

In English legislative genres, binomial and multinomial structures are typical integrative devices to make legislative writing technically accurate and all-inclusive which also provide several possibilities or alternatives for interpretation and application of the provisions (Gustafsson 1975, Bhatia 1993).

Binomials are word pairs or pairs of syntactic sequences connected by a lexical link, usually 'and' or 'or'. There are at least three reasons for the use of binomials in legal English: the need for technical accuracy, the need for precision for the vagueness of the first term and the application of interpretive theory through which the second term serves as a translation to the former (Gustafsson 1984). On the other hand, multinomials are extended nominal binomials that are meant to express the linguistic device of "an enumerative sequence [which] may contain

6 Capítulo III - DOS ÁRBITROS

$\S 50$. O árbitro ou o presidente do tribunal designará, se julgar conveniente, um secretário, que poderá ser um dos árbitros. 
several members, according to the varying situation in the topic we are talking about" (Gustafsson 1975:17).

Although these phenomena contribute to the formality, length and complexity of the sentences, they paradoxically make provisions more transparent insofar as all omissions are supplied for the reader to prevent him/her from drawing unwanted inferences.

Let us examine some lexical binomials and multinomials displayed in the UNCITRAL:

\begin{tabular}{|c|c|}
\hline BINOMIALS & MULTINOMIALS \\
\hline $\begin{array}{r}\text { Null and void } \\
\text { Commenced or continued } \\
\text { Before or during } \\
\text { Arbitrator or arbitrators } \\
\text { The court or other authority specified in article } 6 \\
\text { Independent or impartial } \\
\text { Impartiality or independency } \\
\text { Recognition and (or) enforcement } \\
\text { Award or agreement }\end{array}$ & $\begin{array}{r}\text { Letters, telex, telegrams or other means of } \\
\text { telecommunication } \\
\text { Admissibility, relevance, materiality and weight } \\
\text { Any errors in computation, any clerical or typographical } \\
\text { errors or any errors of similar nature } \\
\text { Correction, interpretation or an additional award }\end{array}$ \\
\hline
\end{tabular}

Table 2: Lexical binomials and multinomials in the UNCITRAL

Syntactic binomials and multinomials are also very common in the UNCITRAL.

[8] Article 15. Appointment of substitute arbitrator. Where the mandate of an arbitrator terminates under article 13 or 14 or because of his withdrawal from office for any reason or because of the revocation of his mandate by agreement of the parties or in any other case of termination of his mandate, a substitute arbitrator shall be appointed according to the rules that were applicable to the appointment of the arbitrator being replace.

Let us visualize the structure of this multinomial: 


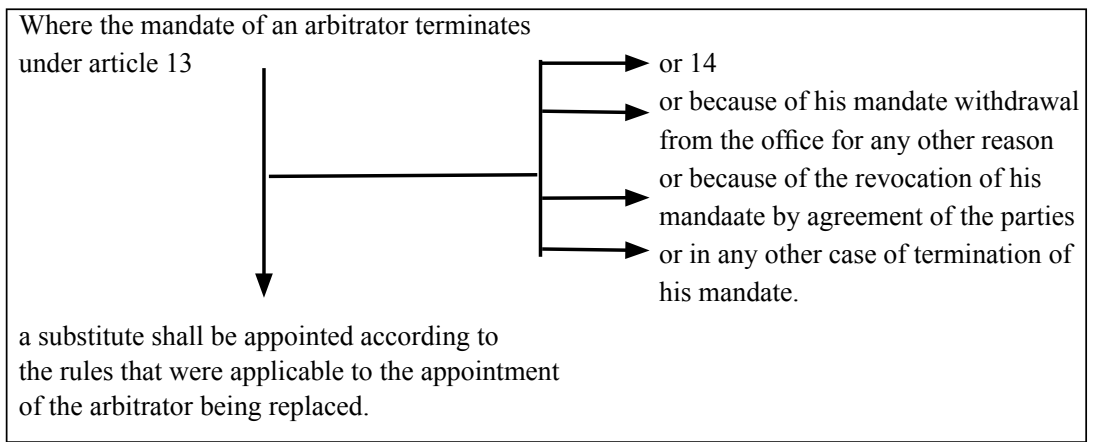

Figure 1

Here the sentence is discontinued syntactically by the insertions of the options provided by the clauses initiated by 'or'. A more complex binomial structure is shown below:

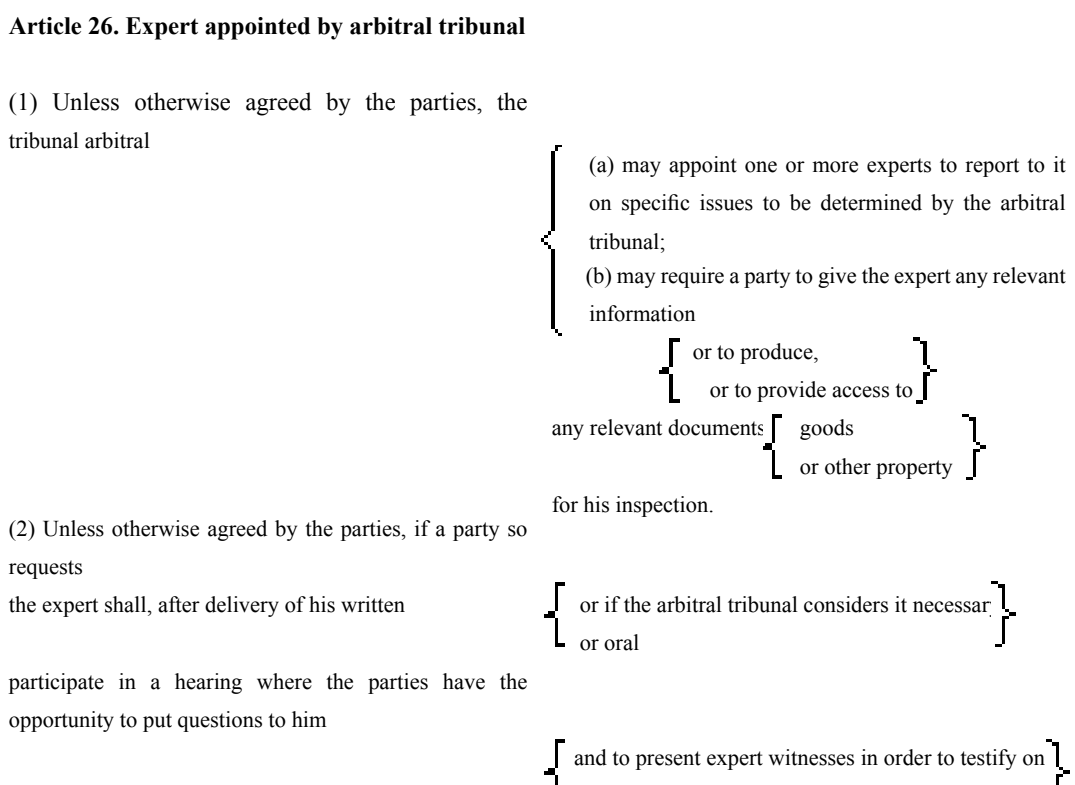

Figure 2 
Binomial and multinomial structures are not typical in Brazilian legal terminology and syntax. Although lexical binomials and multinomials are more frequent than syntactic ones they are sparse and do not share the same rhetorical and historical values as in common law legislative writing. In the BAL, we see both phenomena in example [6]: the binomial 'arbitrator or arbitrators' and the multinomials 'competence, suspicion or impediment' and 'nullity, invalidity or inefficacy'.

The few syntactic structures, as in [9] below, are quite simple compared to the UNCITRAL:

[9] Chapter II. Art.4.

$\S 1^{\text {st }}$ The commitment clause shall be in writing, and may be inserted in the contract itself or in a separate document referring thereto ${ }^{7}$.

The vizualization below shows the simplicity of a syntactic binomial structure in the BAL.

The commitment clause shall be in writing, and

may be inserted in the contracts itself

$\{$ Or in a separate document referring thereto. $\}$

Figure 3

\subsection{Textual-mapping}

In legislative writing, textual-mapping is a type of intratextual recontextualization (see section 6) which serves a text-cohering function to relate various (sub)sections of the same provisions in order to reduce information load at a particular point in the text (Bhatia 1984 and 1993). Textual-mapping involves three main operations: a) spatial and syntactic breaking up of the legislative provision into several itemized or numbered subprovisions; $b$ ) indexing the various subprovisions for ease of reference and c) forward and backward intra-textual crossreferencing to place subprovisions in a wider textual context (Bhatia 1984:6).

7 Capítulo II. Art. 4 o. $\S 1$ 1o A clausula compromissória deve ser estipulada por escrito, podendo estar inserta no próprio contrato ou em documento apartado que a ele se refira. 
Both the UNCITRAL and the BAL make frequent use of textualmapping devices. Let us examine some examples in the data.

\section{[10] Article 6. Court or other authority for certain functions of} arbitration assistance and supervision

The functions referred to in articles 11(3), 11(4), 13(3), 14, 16(3) and 34(2) shall be performed by...[Each State enacting this model law specifies the court, courts, or where referred to therein, other authority competent to perform these functions.]

In [10], the legal content in the UNCITRAL provision is drastically reduced at that point by postponing five further references to 'longdistance' subsections, indicated by the underlined qualification above, "to remind the reader not to read the provision out of context" (Bhatia 1984:6).

[11] 12th Art. The arbitral commitment shall terminate if:

I- any arbitrator declines, before accepting the appointment, provided that the parties have declared, expressly, not to accept a substitute arbitrator;

II- any arbitrator dies or is rendered incapable of voting, provided that the parties have declared, expressly, not to accept replacement; and III- if the time-limit referred to in Art. 11, incise III has expired, provided that the interested party has notified either the arbitrator, or the chairman of the arbitral tribunal, granting him a ten-day period for the preparation and the presentation of the arbitral award ${ }^{8}$.

In [11], the lengthy article of the BAL is broken up into three incises, indexed by ordinal numbering. In incise III, the reference of the underlined qualification is backward and is employed to avoid repeating the provision already mentioned in Article 11, incise III.

8 Art. 12. Extingue-se o compromisso arbitral:

I- escusando-se qualquer dos árbitros, antes de aceitar a nomeação, desde que as partes tenham declarado, expressamente, não aceitar substituto;

II- falecendo ou ficando impossibilitado de dar seu voto algum dos árbitros, desde que as partes declarem, expressamente, não aceitar substituto; e

III- tendo expirado o prazo a que se refere o art. 11, inciso III, desde que a parte interessada tenha notificado o árbitro, ou o presidente do tribunal arbitral, concedendo-lhe o prazo de dez dias para a prolação e apresentação da sentença arbitral. 
Table 3 below summarizes the textual organization and textualization devices displayed in the data.

\begin{tabular}{|l|c|c|}
\hline \multicolumn{1}{|c|}{$\begin{array}{c}\text { Textual ORganization AND } \\
\text { Textualization DEvices }\end{array}$} & UNCITRAL & BAL \\
\hline Textual organization & traditional & traditional \\
\hline Legislative style & easified & traditional \\
\hline $\begin{array}{l}\text { Qualificational insertions } \\
\text { Binomials and multinomials structures } \\
\text { Textual-mapping: }\end{array}$ & & low \\
\hline Self-containedness & high & medium \\
\hline All-inclusiveness & high & light \\
\hline Information load & heavy & low \\
\hline Information spread & condensed & spread and cross-referenced \\
\hline Transparency & high & r \\
\hline
\end{tabular}

Table 3: Textual organization, textualization devices and their degree of significance in the data

Let us now consider legislative recontextualization - more specifically the way in which its general, fuzzy, and vague terms and expressions help interpret the law.

\section{Legislative recontextualization}

One of the most striking features of legal language is the strategic use of 'fuzzy sets' as sources of interpretation "which enables us to construe the discourse in a more flexible manner" (Wagner 2002b:351). Linguistic concepts such as 'fluidity', 'vagueness' 'flexibility' and 'uncertainty' are used quite interchangeably by the author to argue that it is the goal of legislative discourse to employ a quite restrictive frame but without affecting its understanding. 'Flexibility', 'vagueness', as opposed to 'certainty', 'explicitness' and 'precision' in the language of legislation is also approached in Maley (1987 and 1994). Although these concepts share the characteristic of conveying imprecise or unspecified information, they are mostly overlapping and not properly distinguished according to the values they acquire in them legislative genre as tokens of recontextualization. 
Recontextualization ${ }^{9}$ is a dialogistic property of texts (discourses and genres) which provides for "the dynamic transfer-and-transformation" of something from one discourse/text-in-context (the context being in reality a matrix or field of contexts) to another" (Linell 1998a:154). In other words, recontextualization involves the relocation of text parts or aspects of text from one text to another where the relocated elements are subject both to textual change and changes in meaning. These selected "quoted" parts of texts are used as resources in creating new meaning in the "quoting text" and its new communicative contexts (p.155).

But what parts or aspects of text can be recontextualized? According to Linell (1998b:145):

Aspects of discourse which can be recontextualized include linguistic
expressions, concepts and propositions, 'facts', arguments and lines of
argumentation, stories, assessments, values and ideologies, knowledge
and theoretical constructs, ways of seeing things and ways of acting
towards them, ways of thinking, and ways of saying things.

A legislative genre is quintessentially recontextualized insofar as it is constructed "as a mosaic of quotations" as a response to preceding and to subsequent discourses and can be repeated with varying degrees of reinterpretation (Kristeva 1986:37). Viewed in a synchronic perspective, it provides framing devices to the genre into ordered, unified and bounded texts by means of the generation of textuality; viewed in a diachronic perspective, it orders the genre in historical and social terms (Briggs and Bauman 1992).

There are two main types of recontextualization in the legislative genre - intratextuality and intertextuality, - both of which are manifested linguistically by means of terms (words) and expressions. Intratextuality concerns the relations between or within sections and subsections by means of textual-mapping, as seen in section 5.2.

Intertextuality is wider in scope and terms and expressions are available as "resources with potentials" [author's emphasis] (Linell 1998a:119) to be interpreted interactively with contexts in routinized ways. Thus, although word meanings are relatively stable over time,

9 Similar concepts appear in the literature with other terminologies such as responsiveness (Bakhtin 1986), intertextuality (Kristeva 1986), interdiscursivity (Fairclough 2001) and addressivity, other-orientedness and other-orientation (Linell 1998a). 
they are, at the same time, constantly open to negotiation and accommodation either in local (articles, sections and paragraphs) or external contexts of legislation.

Intertextual recontextualization typically involves explicit cross-referencing to other legislation or legal texts. In [12] above, the underlined explicit cross-referencing in the BAL acts metaphorically as a locus to recontextualize the two articles of the Code of Civil Procedure in a new context of application.

[12] $36^{\text {th }}$ Art. It is applied to the homologation for the recognition or enforcement of the arbitral award, as it may apply, the provision under arts. 481 and 484 of the Code of Civil Procedure ${ }^{10}$

Also, intertextuality involves implicit shared specialized knowledge of the meanings of legal principles, concepts and proceedings which are culturally independent and commonly associated with the profession and which ensures "sufficient uniformity" to allow for regular and reliable legislative interpretations (Dascal and Wróblewski 1991). This type of recontextualization is underlined in [13] below taken from the BAL.

[13] Chapter I- General Provisions

$\S 1^{\text {st }}$. The parties may freely agree on the rules of law that shall be applied to arbitral proceedings provided that there is no violation to good customs and public policy ${ }^{11}$.

And perhaps the most relevant of all, intertextuality concerns the legal knowledge of the meanings of the pragmatic generality, fuzziness and vagueness of terms and expressions dependent upon each legal system usage and immediate context of application, as illustrated by the underlined terms and expressions in [14] from the UNCITRAL ${ }^{12}$.

10 Art. 36. Aplica-se à homologação para reconhecimento ou execução de sentença arbitral estrangeira, no que couber, o disposto nos arts. 483 e 484 do Código de Processo Civil.

11 Art. 1o As pessoas capazes de contratar poderão valer-se da arbitragem para dirimir litígios relativos a direitos patrimoniais disponíveis.

12 Ambiguity is also manifested in legislation by the modals 'shall' and 'may'. However, it will not be of concern in this article. For details, see Kurzon 1986, Zhang 1989 and Foley 2002. 
[14] Article 12. Grounds for challenge

(1) When a person is approached in connection with this possible appointment as an arbitrator, he shall disclose any circumstances likely to give rise to justifiable doubts as to his impartiality or independence.

/.../ (UNCITRAL)

Let us make an attempt to distinguish the concepts of generality, fuzziness and vagueness and their linguistic manifestation in legislative recontextualization while providing more examples from the data.

\subsection{Generality}

Generality is not a matter of reference but rather a matter of unspecification, that is, "meaning is general in the sense that it does not specify certain details" (Zhang 1998:16). In legislation, generality is linguistically manifested by means of general classifying nouns and expressions, technical terms, terms of art, legal principles and concepts and proceedings. These terms and expressions are semiotic modes to "conceptualize and classify extra-linguistic realities" (Maley 1987:34) related to the subject matter of the laws, whose meanings are shared by the law-makers and the law-interpreter/applier.

In legislation, general classifying nouns and expressions account for the universality of the law to fit changing circumstances in a changing world - a 'world to word' fit - and they do not specify specific details. As Wagner (2002b:270) also points out:

Une règle de droit n'est pas un discours référencé. Elle se considère comme un discours incluant des actions à venir ou passées. Elle est libre de toute empreinte spatio-temporelle afin de permettre à tout acteur, quel que soit le moment, de la prendre en compte sans en modifier le contenu .

Technical terms, terms of art, legal principles and concepts and proceedings are part of the specialised knowledge of legal practitioners across and within legal systems. A technical term is a special term related to a subject matter whose meaning may change in context over time (Maley 1987); on the other hand, a term of art "is a technical word with a specific meaning" (Mellinkoff 1963:16) and bears the same meaning in whatever context it appears.

Legal principles and concepts have achieved the status of semitechnical words and their meanings have been "interactionally established over time, in the history of practices" (Linell 1998a:121). They 
may be readily understood but are not readily applied and are open to accommodation in new contexts in the future. For example, the reference to 'rules of law' constitutes a long-standing tradition in international arbitration and the arbitrators decide upon universal norms used in the choice of law. The principles of 'usage and good customs' and 'public policy' are stated in Article 17 of the Introduction Law to the Brazilian Civil Code, providing that any law, act and sentence which offend the national sovereignty, public order and good customs is not effective in Brazil. Nonetheless, there are differences between national and international usage and customs. Also, international rules of commerce vary and seem to hold a supranational character in a movement towards the standardization of proceedings to meet the needs of international commerce. And proceedings are the routinized joint activity types which define the situation for the parties.

Table 4 below exemplifies how generality manifests itself in the data.

\begin{tabular}{|c|c|}
\hline $\begin{array}{l}\text { LINGUISTIC MANIFESTATION OF } \\
\text { GENERALITY }\end{array}$ & UNCITRAL \& BAL \\
\hline $\begin{array}{l}\text { General classifying nouns and } \\
\text { expressions }\end{array}$ & $\begin{array}{l}\text { State(s), the party(ies), (no) person, addressee, } \\
\text { witness(es), attorney(s), authority(ies), public servants; } \\
\text { national territory, country, place of business, any places; }\end{array}$ \\
\hline Technical terms & $\begin{array}{r}\text { arbitration, award, arbitral tribunal, challenge(ing), } \\
\text { hearing, appointment }\end{array}$ \\
\hline Terms of art & $\begin{array}{l}\text { waiver, interim measure, claim, recourse, enforcement, } \\
\text { recognition, ex officio, de jure, de facto, exaequo et bono, } \\
\text { amiable compositeur, plea, summon(ing), ipso jure, } \\
\text { petition, coersive measure, injunction relief, pecuniary } \\
\text { liabilities, disposable equity rights (the BAL only) }\end{array}$ \\
\hline Legal concepts & $\begin{array}{r}\text { rules of law, usage and good customs, public policy, } \\
\text { equity }\end{array}$ \\
\hline Proceedings & arbitration proceedings: judicial/extrajudicial arbitration \\
\hline
\end{tabular}

Table 4: Linguistic manifestation of generality in the data 


\subsection{Fuzziness}

Fuzziness is not a matter of the nature of the entity but rather a question of "whether or not an entity is denoted by an expression" (Zhang 1998: 19). A fuzzy term or expression has "no clear-cut referential boundary" and cannot be resolved by linguistic context alone (p.21). In legislation, fuzziness is mainly manifested by terms and expressions indicating users' judgments, that is, words of subjective interpretation. This can be evidenced in legal English dictionaries wherein fuzzy terms take on various definitions according to judges' decisions in court cases (see, for example, the various definitions of 'reasonable' in Black's Law Dictionary 1990). When it comes to civil law legislation, fuzziness can in most cases be resolved by cross-referencing to other codes or legislation and to the constitution.

Fuzziness can be syntactically tested out by posing a 'how' question. For example, Article 1 of the BAL states that "any capable person to a contract may refer to arbitration". If we ask: "How capable is a person to a contract?', the answer is never precise but could be: 'It depends on his/her age'. In Brazilian legal context, this fuzzy term can only be resolved by cross-referencing to Article 9 of the Civil Code which states that a person is 'capable' when he/she reaches his/her 'civil autonomy' at the age of 18 and is in perfect mental condition to answer for his/her actions. This means that he/she can perform all the acts of civil life, including entering into contractual transactions, without the parents' authorization.

Table 5 illustrates the linguistic manifestation of fuzziness in the data.

\begin{tabular}{|l|r|r|}
\hline $\begin{array}{l}\text { LINGUISTIC MANIFESTATION } \\
\text { OF FUZZINESS }\end{array}$ & UNCITRAL & BAL \\
\hline Terms and expressions & $\begin{array}{r}\text { authority competent, justified } \\
\text { doubts, appropriate security, } \\
\text { may consider necessary/ } \\
\text { /(in)appropriate }\end{array}$ & $\begin{array}{r}\text { capable person, expert, } \\
\text { as deemed necessary, reasonable, } \\
\text { competent authority, } \\
\end{array}$ \\
& $\begin{array}{r}\text { convenience of the parties, } \\
\text { relevant documents/goods, } \\
\text { give proper notice }\end{array}$ & \\
\hline
\end{tabular}

Table 5: Linguistic manifestation of fuzziness in the data 


\subsection{Vagueness}

Vagueness is not a matter of referential meaning but of interpretation and concerns terms or expressions which have more than one possible interpretation (Zhang 1998). In legislation vagueness is also manifested by implicature (Channell 1994). In the first case, vagueness in legislation accounts for "the discretion of the courts to construe and apply the rule "correctly", otherwise, it has to be altered, explained or be interpreted by "politically sympathetic judges" (Maley 1987:38).

In the second case, implicature, or "default inference" according to Levinson (2000:11), derives from the law-interpreters' intuitions about a preferred or normal interpretation. From the minimum textual omissions (in common law legislation) and the maximum textual omissions (in civil law legislation) implicature is co-activated by "assessments of situation, principles and cognitive structure formed by framings of experience in terms of linguistic, professional and legal usage conventions" (Frade 2002b:343).

At the syntactic level, vagueness can be tested by posing the question: 'What do you mean by X?', from which a precise answer is expected (Zhang 1998).

Table 6 shows examples of vague language in the data.

\begin{tabular}{|c|c|c|}
\hline $\begin{array}{l}\text { LINGUISTIC MANIFESTATION } \\
\text { OF VAGUENESS }\end{array}$ & UNCITRAL & BAL \\
\hline Nouns & $\begin{array}{r}\text { impartiality, independence, } \\
\text { qualifications }\end{array}$ & $\begin{array}{r}\text { litigation, merit, (in)validity, } \\
\text { (in)efficacy, enforceability, } \\
\text { impartiality, independence, } \\
\text { competence, diligence, discretion, } \\
\text { impediment, suspicion }\end{array}$ \\
\hline Entities & Court & $\begin{array}{r}\text { Court, Judiciary Power, } \\
\text { Supreme Federal Court, } \\
\text { institutional arbitral body/entity }\end{array}$ \\
\hline Rules and Legislation & $\begin{array}{r}\text { national law, statutory rules, } \\
\text { law legal system of a given } \\
\text { State, usages of the trade } \\
\text { applicable to the transaction }\end{array}$ & $\begin{array}{r}\text { Civil Code, Code of Civil Procedure, } \\
\text { criminal law, international rules of } \\
\text { trade, procedural law }\end{array}$ \\
\hline Activities & & to rule, to appoint, to issue \\
\hline
\end{tabular}

Table 6: Linguistic manifestation of vagueness in the data 
Table 7 summarizes the level of frequency of the types of intertextual recontextualization in the data.

\begin{tabular}{|l|r|r|}
\hline $\begin{array}{l}\text { TYPES OF INTERTEXTUAL } \\
\text { RECONTEXTUALIZATION }\end{array}$ & UNCITRAL & \multicolumn{2}{|c|}{ BAL } \\
\hline Generality & high & high \\
\hline Fuzziness & balanced & low \\
\hline Vagueness & low & high \\
\hline
\end{tabular}

Table 7: Types of intertextual recontextualization and their level of frequency in the data

To conclude, both laws seem to confirm the legislative strategy of applying rules to a class of individuals or entities rather than to a single individual or entity and of generalizing rules, principles, proceedings and activities which are not embedded in any external context or in any "surrounding linguistic context (the section or paragraph expressing the rule)" (Maley 1994:28-29). In other words, 'the letter of the law' remains the same despite changes in social and institutional conditions and it is the task of the law-maker/interpreter/applier to assume a change in meaning to make the law appropriate in the light of the current context (Dascal and Wróblewski 1991).

\section{Conclusions}

This article focused on the analysis of the generic variation of two arbitration laws: the UNCITRAL Model Law on the International Commercial Arbitration and the Brazilian Arbitration Law 9.307/1996 in terms of textual organization, legislative style, textualization devices and recontextualization. Some interesting conclusions can be drawn from the analysis.

The UNCITRAL and the BAL present relatively stable textual organization which can be regarded as one of the prototypical cores of legislative genres across legal systems though keeping each traditional legislative style. While the UNCITRAL displays an easified but still traditional legal English style, the BAL displays the reader-friendly civil law style but is not necessarily easier to understand and interpret. 
Also, it becomes evident that the way legislative information is packaged (through the textualization devices analysed) varies a great deal and the information does not take on the same values in the two laws. This can be explained by the difference between the historical, legal and social development of the legal systems they encode. Although highly influenced by the UNCITRAL, the BAL assigns other values to the textualization devices to make them meaningful in the new legal context and it also eliminates the 'excess' of the common law style.

The dialogistic property of recontextualization (intratextuality and intertextuality) is present in both laws and it is the most relevant device to guide wanted interpretation and inferences. The extensive use of general, fuzzy and vague terms and expressions confirm the universal application of the law to fit into new contexts and situations. In the BAL - as opposed to the UNCITRAL - interpretation of these terms and expressions is systematic, and precision can only be achieved by cross-referencing to the codes and the constitution. However, the use of textualization devices, in particular qualificational insertions, can be strategically used to restrict the application of the laws in a given context.

And finally, it is also worth pointing out that the emergence of arbitration laws - such as the model law UNCITRAL and the BAL - has contributed to the popularization of arbitration procedures to correct distortions in domestic laws and to make them more suitable for international, commercial transactions.

Further research is needed to provide for some issues not covered in this article. For example, textualization devices and their values in the civil law legislative style other than the ones presented here should be investigated. And also research into linguistic and discursive strategies may clarify how to accommodate both global and local issues in civil law legislations and contracts under the influence of legal globalization.

\section{References}

Akman, Varol 2000: Rethinking Context as a Social Construct. In Journal of Pragmatics 32, 743-759.

Bakhtin, Mikhail M. 1986: Speech Genres and Other Late Essays. Austin: University of Texas Press. 
Berman, Ruth A. 1989: Syntactic Components of the Foreign Language Reading Process. In Alderson J.C./Urqhart A.H. (eds.): Reading in a Foreign Language. London/New York: Longman, 139-59.

Bhatia, Vijay K. 1984: Syntactic Discontinuity in Legislative Writing and its Implication for Academic Legal Purposes. In Pugh, A.K./ Ulijn, J.M.(eds.): Reading for Professional Purposes- Studies and Practices in Native and Foreign Languages. London: Heinemann Educational Books, 90-96.

Bhatia, Vijay K. 1993: Analysing Genre: Language Use in Professional Settings. London: Longman.

Black, Henry H. 1990: Black's Law Dictionary. $6^{\text {th }}$ Edition. St. Paul, Minn.: West Publishing Co.

Briggs, Charles/Bauman, Richard 1992: Genre, Intertextuality, and Social Power. In Journal of Linguistic Anthropology, 2/ 2, 131-72.

Campbell, Lisbeth 1996: Drafting Styles: Fuzzy or Fussy? E Law- Murdoch University Electronic Journal of Law 3/2 available at: http://www.murdoch.edu.au/elaw/ issues/v3n2/campbel.html

Chafe, William 1976: Givenness, Contrastiveness, Definiteness, Subjects, Topics, and Point of View. In Li, Charles, N. (ed). Subject and Topic. New York: Academy Press, 27-55.

Chafe, William 1984: Cognitive Constraints on Information Flow. In Tomlin, R. (ed.). Coherence and grounding in discourse. Amsterdam: John Benjamins, 21-51.

Channell, Joanna 1994: Vague Language. Oxford: Oxford University Press.

Child, Barbara 1992: Drafting Legal Documents: Principles and Practices. $2^{\text {nd }}$ Edition. St. Paul, Minn.: West Publishing Co.

Danet, Brenda 1980: Language in the Legal Process. In Law \& Society Review, 14/3, 445-564.

Danet, Brenda 1984: Studies of Legal Discourse [Special issue]. In Text, 4, 1-3.

Danet, Brenda/Bogoch Bryna 1994: Orality, Literacy, and Performativity in AngloSaxon Wills. In Gibbons, John (ed.). Language and the law. London: Longman, 100-135.

Dascal, Marcel/Wróblewski, Jerry 1991: The Rational Law-maker and the Pragmatics of Legal Interpretation. In Journal of Pragmatics 15, 421-444.

De Órleans e Bragança, Alberto 1999: Enforcement of Arbitration Agreements in Latin America: Brazil. In Cremades, Bernardo M. (ed) Enforcement of Arbitration Agreements in Latin America. Papers Presented at the 1998 Vancouver IBA Conference. The Hague: International Bar Association and Kluwer Law International, 19-27.

Fairclough, Norman 2001: Discurso e Mudança Social. [Discourse and Social Change] Brasília: UnB. 
Frade, Celina 2002a: Mitigating Conflict in Arbitration Clauses Through Language. In LSP \& Professional Communication, 2/1, 8-26.

Frade, Celina 2002b. The Legal Cooperative Principle: An Essay on the Cooperative nature of Contractual Transactions. International Journal of the Semiotics of Law $15,337: 343$.

Frade, Celina 2003: Introduction to the Legal System in Brazil. In Bhatia, Vijay K/ Candlin Christopher N./Engberg, Jan/Trosborg, Anna (eds.): Multilingual and Multicultural Contexts of Legislation: An International Perspective. Hamburg: Peter Lang GMBH.

Foley, Richard 2002: Legislative Language in the EU: The Crucible. In International Journal of the Semiotics of Law 15, 361-374.

Garcez, José Maria R. 1999: Arbitragem Internacional [International Arbitration]. In Garcez, José Maria M.R. (coord.): A Arbitragem na Era da Globalização [Arbitration in the Era of Globalization]. Rio de Janeiro: Forense, 163-201.

Gibbons, John 1999: Language and the Law. In Annual Review of Applied Linguistics 19, 156-173.

Gustafsson, Marita 1975: Some Syntactic Properties of English Law Language. Turku: University of Turku.

Gustafsson, Marita 1984: The Syntactic Features of Binomial Expressions in Legal English. In Text 4/1-3, 123-41.

Hancher, Michael 1979: The Classification of Cooperative Illocutionary Acts. In Language in Society 8, 1-14.

Hoey, Michael 1986: The Discourse Colony: A Preliminary Study of a Neglected Discourse Type. In Coulthard, Michael (ed.): Talking about text. English Language Research Monograph \#3. Birmingham University, Birmingham, UK, 1-26.

Hogue, Arthur R. 1986: Origins of common law. Liberty Fund: Indianapolis.

Kristeva, Julia 1986: The Kristeva Reader. London: Basil Blackwell.

Kurzon, Dennis 1985": Clarity and Word Order in Legislation. In Oxford Journal of Legal Studies 5/2, 269-275.

Kurzon, Dennis 1986: It is hereby Performed: Explorations in Legal Speech Acts. Amsterdam and Philadelphia: Benjamins.

Levinson, Stephen C. 2000: The Theory of Generalized Conversational Implicature. Cambridge, MA: Bradford Book.

Linell, Per 1998a: Approaching Dialogue. Talk, Interaction and Contexts in Dialogical Perspectives. Amsterdam/Philadelphia: John Benjamins Publishing Company.

Linell, Per 1998b: Discourse across Boundaries: On Recontextualizations and the Blending of Voices in Professional Discourse. In Text 18(2), 143-157.

Luckmann, Thomas 1989: Prolegomena to a Social Theory of Communicative Genres. In Slovene Studies 11/1-2, 159-166.

Maley, Yon 1987: The Language of Legislation. In Language in Society 16, 25-48. 
Maley, Yon 1994: The Language of the Law. In Gibbons, John (ed): Language and the Law. London: Longman, 11-49.

Mellinkoff, David 1963: The Language of the Law. Boston: Little, Brown and Company.

Miller, Carolyn 1984: Genre as Social Action. In The Quarterly Journal of Speech 70/1, 151-167.

Paltridge, Brian 1995: Working with Genre: A Pragmatic Perspective. In Journal of Pragmatics 24, 393-406.

Quirk, Randolph, Greenbaum, Sidney, Leech, Geoffrey \& Svartvik, Jan 1985: A Comprehensive Grammar of the English Language. London: Longman.

Trosborg, Anna 1997: Rhetorical Strategies in Legal Language: Discourse Analysis of Statutes and Contracts. Tübingen: Narr.

Van Dijk, Teun A. 1977: Context and Cognition: Knowledge Frames and Speech Act Comprehension. In Journal of Pragmatic 1, 211-232.

Zariski, Archie 2000: Disputing Culture: Lawyers and ADR. E Law - Murdoch University Electronic Journal of Law, 7/2, available at: http//www.murdoch.edu.au/ elaw/issues/v7n2/zariski72 text.html

Zhang, Qiao 1998: Fuzziness - Vagueness - Generality - Ambiguity. In Journal of Pragmatics 29, 13-31.

Wagner, Anne 2002b: La Langue de la Common Law. Paris: L'Harmattan.

Widdowson, Henry, G. 1979: Explorations in Applied Linguistics. Oxford: Oxford University Press. 
